\title{
SOCIOLOGICAL STUDY ON THE CONDITIONS OF MIGRANT WORKERS IN THE GARMENT INDUSTRY IN ERNAKULAM CITY POST 2018 FLOODS
}

\author{
Sudha Krishnakumar \\ M O P Vaishnav College for Women, \\ Chennai, Tamilnadu, India
}

\begin{abstract}
Internal migration or movement of people within a country has been historically viewed as a coping strategy for earning a livelihood. There is more than enough evidence of both voluntary and forced migration, which may be the result of pull factors like search for better livelihood options and push factors like natural disasters, a failed monsoon and the consequent famine, Poverty and indebtedness are the most important factors that lead to migration. Workers migrating within a country usually move from less developed regions to more developed ones. Kerala has been one of the most promising destinations for migrants from north and north-east India mainly due to the higher earning potential and lesser harassment by the authorities. The devastating floods of August 2018 led to the complete disruption in the lives of these migrant workers. The present paper is an attempt to look into the conditions of the migrant workers in the garment industry in Ernakulam city after the floods. The resettlement and rehabilitation efforts of the Government post flood scenario and the new schemes that would help them to cope with any future calamities have also been examined in detail.
\end{abstract}

Key word: migrant workers, floods, kerala, garment industry.

Cite this Article: Sudha Krishnakumar, Sociological Study on the Conditions of Migrant Workers in the Garment Industry in Ernakulam City Post 2018 Floods, International Journal of Management, 10 (4), 2019, pp. 68-75.

http://iaeme.com/Home/issue/IJM?Volume=10\&Issue $=4$

\section{INTRODUCTION}

Migration is the measuring tool of changing socioeconomic and political conditions at the national and international levels. It can also be seen as a sign of wide disparities in economic and social conditions between the migrants' places of origin and destinations. In developing countries like India, migration mostly takes place due to the push factors at the place of origin which translate into causes like poverty, unemployment, natural calamities and underdevelopment. As far as Kerala is concerned, migration has played a crucial role in the 
development of the state. Nearly three million non-resident Malayalis, mostly from the west Asian countries contribute to the state's economy to the tune of more than one-third of the State Domestic Product that is about 90,000 crore. According to various studies, the human development in the state can be considered to be substantially ahead of a majority of other Indian states. Kerala has also witnessed advanced demographic transition as well as its consequences. The acute shortage of local labour force to take up low-skilled low-valued jobs in the informal sector and dirty physical labour have stimulated the era of replacement migration in Kerala and migrant workers from other states are occupying an important and indispensable role in the economy of the state. Kerala has emerged as one of the most desirable and income generating destinations among the Indian states for migrant workers from many of the major states known for out-migration in the country.

There is a lack of accurate migration data but a study commissioned by the state government in 2013 estimated that there were roughly 25 lakh interstate migrant workers in the state. They are regarded as wealth creators of Kerala state in many sectors. The growth of Kerala economy is a paradox. There is a high rate of unemployment at $12.5 \%$ and yet a population unwilling to do low-skilled jobs.

In these murky waters swim the swarm of migrants. Almost all the low level jobs in Kerala other than the beedi industry and headload workers - as they are fully under the control of the trade unions, are dominated by workers from West Bengal, Odisha, UP, Bihar and Assam. A minority are also from Jharkhand and Chattisgarh. Construction is one area where they dominate the most. Women are mostly employed in the plantation and other domestic jobs sector.

Yet they are out of the good eyes of the government. They are forced to live and work in crowded slums and hazardous locations. The poor living conditions have raised fears of the spread of diseases among the local people. "The profile of a migrant worker is a single male, 15-35 years old from the tribal, SC or Muslim community," says Benoy Peter, Director of the Perumbavoor-based Centre for Migration and Inclusive Development (CMID).

Kerala seems to be a better place to work for these migrants because of the high wages, relatively less exploitation by contractors, and less harassment by authorities but whenever there is a crime reported to have been committed by a migrant, local people and media have amplified it and had led to instances of violence against them too. The local people also seem to have a lack of trust towards these workers in spite of them being everywhere including vegetable and grocery shops. Most of them have picked up the local language just enough to communicate with their contractors and employers, and some are experts in Malayalam.

In the year 2018, Kerala witnessed an unprecedented event. It experienced $42 \%$ more rainfall in the months of July and beginning of August leading to catastrophic consequences. Landslides and floods wreaked havoc. Almost 450 people lost their lives and damage to property was estimated to be 650 crores. In such a scenario, almost $90 \%$ of the migrant communities returned home after they found that their jobs became non-existent and the sources of income drying up. Another factor that contributed to their return to their native places was the availability of free trains to their native places being provided by the Indian railways after much pressure from their respective state governments. After three months, almost $85 \%$ of them returned to Kerala.

Against this background, the present study attempts to examine demographic and socioeconomic status of the migrant workers engaged in the garment manufacturing units in the city of Ernakulam. More precisely the paper examines the reasons for their return and rehabilitation work done for them, their living conditions and reasons of migration to Kerala. The paper also attempts to look at all the welfare measures that have been done post the flood scenario by the Government and other voluntary organizations in order to create a better lifestyle for thses migrants who are the major workforce in all the sectors od employment in Kerala 


\section{DATA AND METHODOLOGY}

The paper is based on primary survey data on the migrant workers in Ernakulam city. The selection of the Ernakulam is based on the concentration of migrant workers in different garment manufacturing units of the city. Most of these units fall under the unorganized sector. Help has been taken from the local people for identifying the garment manufacturing units where the migrant workers have been working and also to identify the places where they have been living. Data has been collected from their workplaces as well as their houses. Permission was taken from their supervisors or owners of the establishments so that the respondents could spend the necessary amount of time to answer the questions without worrying about their productivity. Information was collected about particulars such as the reasons of migration, sources of information about their destination city, their past and present occupational pattern, their plight during the flood and their resettlement and rehabilitation after their displacement as a result of the floods.

A total of 140 migrant workers have been interviewed by using a pre-tested semi-structured questionnaire. The analysis carried out in this paper is descriptive.

\section{FINDINGS}

Typical characteristics of a migrant

Table 1 provides an insight into the typical characteristics displayed by the sample migrants in the garment industry of Ernakulam city. The sample comprises of almost $72 \%$ of migrants below the age of 40 and $24.29 \%$ between 30 and 40 . Only a very small percentage of workers were above the age of $40(4.28 \%)$. The pull factors in the place of destination seems to have attracted the young, mainly unmarried (50.72) youth. The married migrants also did not bring their families to Kerala. Interviews with the migrants brought out this fact also. The migrants mostly belonged to the Hindu religion $(84.28 \%$ ) while there was a small representation from the Muslim (10.72) and Christian (5\%) community also. A majority of them had secondary education $(45 \%)$ or at least primary education $(41.43 \%)$ but there were also some non-literates $(12.15 \%)$ among them. The term non literate has been used deliberately to point out that they could write their names but could not read or write anything else. Most of these workers had poor economic background and to confirm that the study also wanted to know their occupations before their migrated to Kerala.

Table 1 General characteristics of the Migrants

\begin{tabular}{|c|c|c|}
\hline Age & Frequency & Percentage \\
\hline Below 20 & 23 & 16.43 \\
\hline $20-30$ & 77 & 55 \\
\hline $30-40$ & 34 & 24.29 \\
\hline Above 40 & 6 & 4.28 \\
\hline Total & 140 & 100 \\
\hline
\end{tabular}

\begin{tabular}{|c|c|c|}
\hline Religion & Frequency & Percentage \\
\hline Hindu & 118 & 84.28 \\
\hline Muslim & 15 & 10.72 \\
\hline Christians & 7 & 5 \\
\hline Total & 140 & 100 \\
\hline
\end{tabular}


Sociological Study on the Conditions of Migrant Workers in the Garment Industry in Ernakulam City Post 2018 Floods

\begin{tabular}{|c|c|c|}
\hline Marital status & Frequency & Percentage \\
\hline Unmarried & 71 & 50.72 \\
\hline Married & 67 & 47.86 \\
\hline Widowed & 2 & 1.42 \\
\hline Total & 140 & 100 \\
\hline
\end{tabular}

\begin{tabular}{|c|c|c|}
\hline Educational status & Frequency & Percentage \\
\hline Non literate & 17 & 12.15 \\
\hline Primary schooling & 58 & 41.43 \\
\hline SSLC & 63 & 45 \\
\hline Graduate & 2 & 1.42 \\
\hline Total & 140 & 100 \\
\hline
\end{tabular}

Table 2 Occupation before migration

\begin{tabular}{|c|c|c|}
\hline Occupation & Frequency & Percentage \\
\hline Student & 7 & 5 \\
\hline Unemployed & 14 & 10 \\
\hline Employed & 22 & 15.71 \\
\hline Self employed & 58 & 41.43 \\
\hline Agriculture & 39 & 27.86 \\
\hline Total & 140 & 100 \\
\hline
\end{tabular}

Most of the studies conducted about the migrant workers occupations before reaching Kerala have shown that the majority were self-employed in the agriculture sector but the present study had a different result. It is clear from Table: 2 that $41.43 \%$ were self-employed but they were all working as tailors having small shops in the urban fringes of various cities where the wages were very poor. The garment industry in Kerala was an opportunity to increase their earning power and has thus resulted in a large scale migration of skilled tailors and embroidery workers from the various states. A state-wise break- up of the migrants will enable us to see a clearer picture. West Bengal dominated this sector with 55\%, while Odisha and Uttar Pradesh followed with 20 and $15 \%$ respectively. The garment industry requiring certain skill levels before entry proved to be a difficult sector for migrants from Bihar (7.14\%) and Assam (2.16\%).

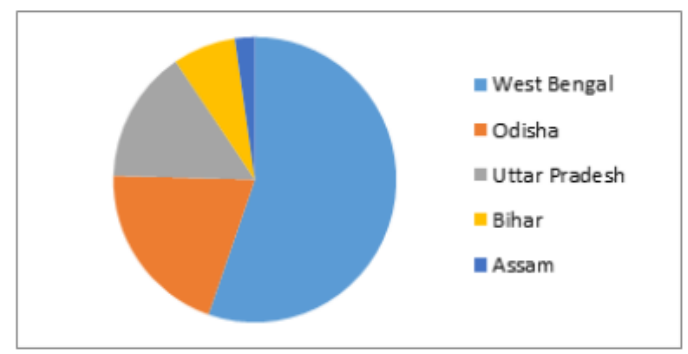

Figure 1

The garment industry in Ernakulam is dominated by privately owned small scale customized stitching units $(37.14 \%)$ with most of them having their own embroidery units (25.72) too. Few large scale units also were found in some locations (16.43\%). There have been no earlier studies done in this sector and the workers were eager to share their experiences during and after the flood. 
Table 3 Migrants in the types of Garment Industry

\begin{tabular}{|l|c|c|}
\hline \multicolumn{1}{|c|}{ Types of Industry } & Frequency & Percentage \\
\hline Stitching units organized sector & 23 & 16.43 \\
\hline Stitching units unorganized sector & 52 & 37.14 \\
\hline Embroidery units organized sector & 29 & 20.71 \\
\hline Embroidery units unorganized sector & 36 & 25.72 \\
\hline Total & 140 & 100 \\
\hline
\end{tabular}

Almost all these migrant workers stayed in small cramped dormitories or small apartments and cooked their own food after returning from work everyday. On the night of August 8, 2018 the workers were cooking their evening meal inside their houses. The incessant rain was not worrying them at that point but soon after, water started entering their dwellings and they were forced to flee with their meager possessions and take shelter elsewhere. Those employed in the organized sector were allowed to stay within the unit premises on higher locations but the majority of workers took shelter under flyovers and metro rail constructions. They were forced to stay there for 2-3 days. Volunteers and rescue workers provided food but shelter was unavailable. After a few days they could shift to relief camps that were opened by the Government. As the flood waters receded, many required help to clean their houses and these workers earned some money by doing these menial jobs. Their respective state governments had also requested the Railways to run special trains to take them home.

Almost $90 \%$ of the migrant workers irrespective of the industry they were working in, left for their home state. All the respondents $(100 \%)$ of the present study said that they had gone back after the floods and returned only after two months. By the time they returned, all their jobs were back but unanimously all of them said that they had not got any financial help from anyone. The Government had promised Rs10,000 as compensation for lost belongings but none of the migrants could claim the amount as they did not have any identity card issued in Kerala. $87.14 \%$ of workers had either Aadhar card or voter's ID from their native place while $12.86 \%$ did not possess even that.

Table 4 Identity cards of workers in garment Industry

\begin{tabular}{|c|c|c|c|c|}
\hline & Issued by Home state & Percentage & Issued in Kerala & Percentage \\
\hline Workers with ID cards & 122 & 87.14 & 3 & 2.14 \\
\hline $\begin{array}{c}\text { Workers without ID } \\
\text { cards }\end{array}$ & 18 & 12.86 & 137 & 97.86 \\
\hline Total & 140 & 100 & 140 & 100 \\
\hline
\end{tabular}

As the majority of workers were from the unorganized sector they could not claim any compensation from their owners also. Almost $75 \%$ of the respondents said that after their return, they were not paid even the remaining wages that they should have been paid because their employers told them that they had lost a lot of money and material. In spite of all these adversities the migrant workers have persisted with their employers and also helped to rebuild their business.

In the last few months, reports of various Government agencies about the aftermath and rebuilding measures undertaken to restore normalcy in the state recognized the plight of the migrant workers in the unorganized sectors like the garment industry and recommended certain schemes to be put in place so that a repetition of August 2018 does not occur. Some of the schemes have been presented in this study.

Awaz Health Insurance is a state government initiative developed by the government of Kerala to provide health insurance and accidental death coverage for migrant workers living in the state. This scheme can be utilized by migrant labourers between the ages of 18 and 60 . At the time of enrolling in the scheme, all the, labourers must provide their fingerprint, iris, and 
other work-related proof. Once these details are provided, the Awaz insurance card will be issued to the worker.

To its credit Kerala can proudly say that it is the first state in India to enact a social security scheme for all the different migrant workers. A start has been made but a comprehensive legislation for migrants' welfare is still not complete. The Kerala Migrant Workers Welfare Scheme 2010 is a scheme that provides a registered migrant four benefits:

- Accident/ medical care for up to Rs 25,000

- In case of death, Rs1 lakh to the family

- Children's education allowance

- Termination benefits of Rs 25, 000 after five years of work.

In addition to these benefits, if a worker dies, the welfare fund will provide for the embalming of the body and air transportation.

To avail of all these benefits, a worker needs to register with the scheme. The membership also has to be renewed every year by paying a nominal charge of Rs 30. According to Government sources, in Ernakulam city, which has the largest migrant population in the State, almost 8,200 migrants had joined the scheme. About 500 of them have renewed their membership regularly, which was essential for getting the terminal benefits. The government has also started issuing pamphlets in Hindi so that they understand the scheme better.

The Kerala Interstate Migrants Alliance for Transformation (KISMAT), is another initiative in Kerala, not by the government but by the Don Bosco Salesian houses of the State to protect rights of migrant workers and ensure their welfare. KISMAT is an attempt to reach out to migrant workers who have no to access to entitlements such as food, shelter, education, medical care and so on after the massive floods. There will be 12 helpdesks set up in various districts of the state and these will ensure the migrant workers will get skill training. It is also meant to empower them to overcome work-related problems, help them access education for their children, provide them with free legal support and counselling, and ensure their mental and social welfare by linking them with all the different services provided by the State such as food, education, and health.

Kerala has always been hailed nationally and internationally for the sound social security and welfare measures it has extended to its working classes for many years. The policy of the Government of Kerala states that every employee or worker should be a member in any of the Welfare Board and welfare support they must be provided by the State throughout their lives. Accordingly, about 45 lakh of labour force in the State of Kerala are supported under any one of the Social Security schemes (Jacob John, 2015). There are 19 Labour Welfare Fund Boards under the Department. The Labour laws and Labour welfare schemes implemented by state is much higher than that of other states in India (Government of Kerala 2013). In contrast to these enormous benefits of the locals, migrant labourers in Kerala do not get the benefit of any of these welfare measures. Both employers of migrant labourers and government institutions at state level or national level do not heed their problems. The migrants are completely unaware of the legal and social security measures in Kerala, the host state. They do not have access to education related schemes, health services schemes and social security scheme. It is this negligence and indifference that has cost them a lot while seeking compensation for their losses incurred during the 2018 floods. It is all the more unfortunate that trade unions are not really concerned about the welfare of domestic migrant labourers. Most of the migrant labourers are unaware of their rights and do not know who to approach to present their grievances.

The present study also found that some of the employers do not register their workers with the labour department to escape from liabilities and reduced employer benefits. It is for the best interest of all the stake-holders concerned -migrant labourers, employer, local community and 
state government, that all migrant workers are registered. This will also serve to reduce the negative perception among the local population that these labourers are not trustworthy.

\section{CONCLUSION}

The Government of Kerala, in co-ordination with its Labour department and the services of the numerous NGOs working in the field can effectively track all the migrant workers and register them in the appropriate bodies if efforts are made sincerely. Kerala has seen an increase in some vector borne diseases that were almost eradicated from the state, resurface as a result of these migrant workers bringing it from their native states. Such issues may also be addressed if the department of health is also involved efficiently. A medical insurance scheme may be introduced for them. The Department of Health can introduce a system of registration at the level of primary health centres and community health centres too.

The Home department with its network of police stations, and the department of social welfare along with the local government institutions, trade unions and voluntary organizations should be involved in tracking migrant labourers in Kerala. In 2017 the devastating Ockhi cyclone hit some coastal districts of Kerala and these migrants say that many of their people who had gone on the fishing boats were missing but as they were not registered crew members nothing was done about them. The numbers are still not clear.

To avoid such future occurrences and to create a sense of belonging for these workers and also for being accepted by the local population, a system of registration needs to be started. This system needs to be formulated at the state level instead of private groups like the Don Bosco Society which is doing stellar work in this regard. Just like the KISMAT scheme, a facilitation desk can be set up in Panchayat/ Municipality to track the inflow and outflow of labourers. Specific guidelines may be issued to contractors, residences and individual who employ these migrant labourers regarding the registration process. Some employers do not register the names of migrant labourers who are under their employment with the labour department deliberately so they can escape from liabilities of providing benefits to the employees. To counter this stance, registration cards can be made compulsory if they need employment and that should be made the responsibility of the employers to procure it for the migrants.

Migrant labourers should be able to get the benefits of public distribution system in Kerala. Just like postal ballots are enabled for exercising their voting rights, there should be a portability that ensures insurance schemes and other food supplies and medical benefits for them if they are already enrolled in such schemes in their home state. The study found that these migrant workers reside in Kerala for 8-10 months in a year. Access to the BPL (Below Poverty Line) ration cards from PDS shops in Kerala will help in bringing a positive change in the nutritional level of these families and also help in increasing their saving potential for which they have migrated in the first place.

Most of the respondents were living in small apartments that are over crowded. 10-12 of them stay in a single room and access to basic amenities like clean drinking water and sanitation are lacking. The Government is also aware of these problems and have plans to build low cost housing complesxes for them. A beginning has been made in Palghat district. The pilot scheme called the 'Apna Ghar Project - Palakad Scheme' can accommodate 620 male interstate migrant workers in a ground plus three floor hostel complex at Kanjikode, Palakkad.Accommodation will be available at a nominal rent. The hostel provides shared residential rooms with bunk beds, indoor bathrooms, toilets, clothes washing and drying areas, kitchens, mess areas, recreational facilities, etc. The hostel also boasts of safety features like a fire fighting system, 24 hours security and CCTV system, conservation awareness related rain water harvesting system, diesel generator system etc to its credit. This has become operational since February 2019. Such schemes should be extended to other districts also. 
A project called 'Roshni' has been initiated by the government of Kerala for motivating the children of the migrant workers to take up education in their new place. Most of these children have dropped out of school as they do not know the local language. BPCL-Kochi Refinery chipped in with the funds needed to roll out the project as their CSR initiative. Roshni aims at making the learner proficient in instructional language using code-switching as the pedagogical tool. This means that the speaker alternates between two or more languages or language varieties, including graphic (visual) learning, in the context of a single conversation. To find volunteers who were proficient in two languages was difficult but it is slowly making inroads. Adding a nutritious breakfast in the scheme has also helped to bring in more children.

All the migrant labourers in Kerala possess mobile phones and these are their lifelines. Their communication with family and friends back home and in their new found friends in Kerala are entirely through this communication device. Using this technology the government should convey latest information related to government programmes, schemes, rights etc in their local language. Essential information about minimum wages, registration system in Kerala, etc and creating awareness about their rights on wages, living conditions, insurance, etc can also be done. Periodical inspection of labour camps and worksites by the concerned authorities should be the undertaken to minimize various malpractices of employers.

A beginning has been made but it is only the tip of the iceberg. Although the migrant workers did not receive any monetary compensation after the floods, most of them have returned and the Government and voluntary organizations have woken up to the fact that they are the backbone of the manual labour force in Kerala. Many projects are in the pipeline and the future appears to be better than what was in the past.

Migration needs to be facilitated through proper development initiatives and strategies so that its benefits can be maximized at all levels.

\section{REFERENCES}

[1] Rajan, S.I., \& James, K.S, Demographic Transition and Economic Development in Kerala: The Role of Emigration. South Asia Network of Economic Research initiatives,2007

[2] Anna V. Vinokurova, Anna Yu. Ardalyanova, Elena Yu. Kostina, Nadezhda A. Orlova and Ilya V. Kupryashkin, Family in the Structure of Life Values of Female Migrant Workers (As Exemplified by Empirical Research), International Journal of Civil Engineering and Technology, 9(11), 2018, pp. 173-179.

[3] Saikia, Dilip, the Socio-economic Status of Migrant Workers in Thiruvananthapuram District of Kerala, India. Journal of Economic and Social Thought. Volume 3, Issue 1, 2016

[4] Prashant Singh, LGBT Diversity and Inclusion at Workplace - An Analysis of Changing Demographics. International Journal of Marketing and Human Resource Management, 9(2), 2018, pp. 22-25

[5] Staff Reporter, KISMAT for Migrant Workers Launched. The Hindu. Thiruvananthapuram, 2019

[6] Peter Benoy \& Vishnu Narendran, God's Own Workforce: Unravelling Labour Migration to Kerala. Centre for Migration and Inclusive Development, Perumbavoor, Kerala, 2017

[7] Mr. M. Praveen Sandeep and Dr. N. Kannan, Role of Employee Demographics and Work Preferences in the New Product Development in Fabrication Engineering Industry. International Journal of Civil Engineering and Technology, 7(4), 2016, pp. 565-575.

[8] Government of Kerala, Kerala Post Disaster Needs Assessment. Floods and Landslides, August 2018.

[9] Padmanabhan, Ananda. J, Status of Migrants from Other States to Kerala - Need for Development Initiatives, IRACST - International Journal of Commerce, Business and Management (IJCBM), ISSN: 2319-2828, Vol.5, No 1, Jan-Feb 2016 